Paweł Panas

Instytut Literaturoznawstwa, Katolicki Uniwersytet Lubelski Jana Pawła II

\title{
Spór o istotę zła. Hannah Arendt w pismach
} Gustawa Herlinga-Grudzińskiego

\section{Hannah Arendt}

Hanna Arendt po raz pierwszy pojawia się w pismach Gustawa Herlinga-Grudzińskiego w 1963 roku jako autorka niedawno wydanego Eichmanna w Jerozolimie. Rzeczy o banalności zła (Eichmann in Jerusalem. A Report on the Banality of Evil [Arendt 1963]; włoskie tłumaczenie: La banalità del male. Eichmann a Gerusalemme [Arendt 1964]). Książce tej poświęca pisarz osobny esej zatytułowany Demon Naszych Czasów, który wchodzi do opublikowanego w Paryżu, w serii Biblioteka Kultury, tomu Drugie Przyjście oraz inne opowiadania i szkice [Herling-Grudziński 1963]. Bardzo szybka reakcja Herlinga-Grudzińskiego na anglojęzyczną publikację (polskie tłumaczenie dzieła Arendt autorstwa Adama Szostkiewicza ukazało się w Krakowie blisko ćwierć wieku później, w 1987 roku nakładem wydawnictwa Znak) nie była jednak - jak mogłoby się wydawać - wyrazem chwilowej intelektualnej fascynacji. Sam

1 Zważywszy na ukierunkowanie zainteresowań pisarza oraz swobodny dostęp do książek i prasy światowej, szybka reakcja nie jest niczym zaskakującym, wszak książka Arendt od samego początku wzbudzała gorące spory i uruchomiła nierzadko emocjonalnie nacechowane polemiki. Pełne ich zestawienie i drobiazgowe omówienia przynoszą prace Richarda J. Bernsteina [1996], Klausa Nau- 
pisarz, nieskory przecież do wygłaszania tego rodzaju autokomentarzy, w jednej z rozmów prasowych stwierdził po latach, że esej ten należy do tych tekstów, z których był i nadal jest wyjątkowo dumny [Herling-Grudziński 20oob: 17]. Jednak o randze i trwałości Herlingowego zainteresowania dziełem Arendt dobitnie świadczy przede wszystkim liczba zapisów w ten czy inny sposób jemu poświęconych, które na przestrzeni wielu lat pojawiły się na kartach Dziennika pisanego nocą. Niejednokrotnie są to obszerne zapisy dziennikowe, sprowokowane różnego rodzaju okolicznościami zewnętrznymi, chociażby pierwszym wydaniem polskiego tłumaczenia [Herling-Grudziński 2018: 328-329]. Zwraca jednak uwagę także stałe powracanie do głównych tez pracy Arendt przy okazji częstych u Herlinga-Grudzińskiego rozważań poświęconych zagadnieniom xx-wiecznych ideologii, przemianom cywilizacyjnym, które dokonały się po II wojnie światowej, oraz przede wszystkim problematyce zła (nie tylko postrzeganego przez pryzmat etyki, ale także analizowanego z uwzględnieniem kontekstu ściśle metafizycznego i religijnego) - by pozostać tylko przy kilku najważniejszych tematach, jakie odnajdujemy w swoistej summie życia autora Innego Świata [zob. Kudelski 1991; Bolecki 2005: 99-110].

Swoje uznanie dla Arendt Herling-Grudziński, z natury bardzo surowy oraz bezkompromisowy krytyk, wyrażał wielokrotnie i w sposób jednoznaczny. I tak we wspomnianym już wcześniej zapisie datowanym na 11 marca 1988 roku możemy przeczytać:

W Polsce wyszedł nareszcie Eichmann w Jerozolimie Hanny Arendt, autorka Źródeł totalitaryzmu została pośmiertnie ułaskawiona przez nadwiślańską cenzurę. Książka znakomita, w pewnym sensie odkrywcza, poprzez proces Eichmanna rzucająca na Holocaust dużo nowego światła. Jej odkrywczość tkwi w podtytule: Raport o banalności zła. [Herling-Grudziński 2018: 328]

manna [1994] i Daniela Heitzmanna [2008]. Kontrowersje wokół pracy Arendt, które z uwagą śledził Gustaw Herling-Grudziński, referuje również Julia Kristeva [2007] w biografii autorki Korzeni totalitaryzmu. 
Cytat ten, spośród wielu podobnych, został wybrany przeze mnie nieprzypadkowo. Otóż pojawiają się w nim dwa główne elementy Herlingowej lektury Arendt. Po pierwsze, była ona dla polskiego pisarza przede wszystkim autorką Eichmanna $w$ Jerozolimie, a więc książki, którą Herling-Grudziński [1998: 253-256] wprost określał jako rzecz „znakomitą” i „najgłębiej sięgającą do istoty Zagłady”2. Inne pozycje z dorobku Arendt, chociażby wspomniane już wcześniej Korzenie totalitaryzmu [Arendt 1993] oraz listy do Karla Jaspersa [Arendt, Jaspers 1992], pojawiają się w rozważaniach pisarza jedynie okazjonalnie. Po drugie, może jeszcze ważniejsze, Arendt była dla Herlinga-Grudzińskiego autorką rewelacyjnej tezy o „banalności zła” [zob. Bolecki 2005: 34]. Jak podkreślał w rozmowie z dziennikarzem włoskiego miesięcznika „Una Citta”: „Już samo to określenie, użyte w tytule książki o procesie Eichmanna, stawia Hannę Arendt w czołówce myślicieli naszego stulecia” [Herling-Grudziński 1998: 717].

W tym kontekście warto także przypomnieć, jak wiele lat wcześniej autor Innego Świata z aprobatą cytował opinię Milovana Dżilasa, który miał się wyrazić o Arendt, że to „jeden z najprzenikliwszych umysłów analitycznych naszych czasów” [Herling-Grudziński 2017: 432]. Już na pierwszy rzut oka uderza w obu

Co ciekawe, równie dobrze wypowiadał się pisarz na temat Rozmów z katem Kazimierza Moczarskiego. 10 lipca 1978 roku notował w swoim Dzienniku... : „Rozmowy z katem Moczarskiego są książką niebywałą, przewyższającą chwilami Eichmanna w Jerozolimie Hanny Arendt. Nic tak jak pobyt w celi więziennej, monotonia życia za kratami przerwana nagle posiadaniem pilnego i uważnego słuchacza, nie pobudza ostrego głodu obnażania się, nie wywołuje tej szczególnej dyspozycji psychologicznej, w której wzdęciu próżności i szczerości prymitywa towarzyszy natychmiast biegunka elokwencji. Śledztwo, ekspertyzy biegłych, są (jak w przypadku Eichmanna obserwowanego przez Hannę Arendt) to mniej czy więcej skuteczne środki na wstrzymanie" [Herling-Grudziński 2017: 364]. Jak widzimy, książka Arendt stanowiła więc dla pisarza swoisty punkt odniesienia, czemu dawał wyraz niejednokrotnie, np. w ocenie noweli Georga Steinera The Portage to San Cristobal of A.H., o której pisal: „Zdobyłem tę nowelę przed wyjazdem na wakacje i wczoraj przesiedziałem nad nią pół nocy. Oszołomiony? Zbulwersowany? Wykołowany? Raczej nie bardzo własnym oczom dowierzając, że po raporcie o «banalności zła» Hanny Arendt (sprawozdaniu z procesu Eichmanna w Jerozolimie) można się było pokusić o próbę rzucenia na to samo zło światła patosu historycznego, swoistego co prawda i wieloznacznego, ale przecież patosu [...]” [Herling-Grudziński 2018: 37]. 
przytoczonych cytatach zbieżność opinii i sformułowań użytych do ich wyrażenia.

Herlingowe omówienia Eichmanna w Jerozolimie oraz jego eksplikacja zasadniczej tezy o „banalności zła” nie odbiegają od utartych ścieżek interpretacyjnych - z jednym wszakże istotnym wyjątkiem, na który przyjdzie jeszcze zwrócić uwagę w dalszej części wywodu. Pisarz w swoich analizach pozostaje wierny literalnym znaczeniom oryginalnego tekstu, często nie wykraczając poza ramy standardowej procedury streszczającej. Ciekawe i godne osobnego namysłu jest natomiast potraktowanie tytułowej tezy Eichmanna $w$ Jerozolimie w sposób uniwersalny i rozszerzenie jej pola oddziaływania daleko poza macierzysty kontekst, w którym po raz pierwszy zaistniała ${ }^{3}$. O ile Arendt opisywała w swojej relacji szczególny i zaskakujący wymiar niemieckiej machiny zagłady narodu żydowskiego - choć oczywiście w tle pojawiały się u niej także inne przykłady ludobójstwa (chociażby zbrodnia katyńska) o tyle dla Herlinga-Grudzińskiego „banalność zła” była genialną formułą. Precyzyjnie oddawała istotę wszelkich ideologii, których fundament stanowiło lub stanowi wielopoziomowe odczłowieczenie, w różnym stopniu i zakresie, oprawców i ofiar, a konsekwencją była lub jest ich nieredukowalna zbrodniczość. Oczywiście tak rozumiana koncepcja nie może rościć sobie prawa do historycznej uniwersalności, ale Herling-Grudziński [2017: 402] dostrzegał, że może ona być odczytywana w granicach wyznaczanych przez cezurę nastania epoki, którą dosyć enigmatycznie określał mianem „ery społeczeństw masowych”. Jedną z charakterystycznych cech owych społeczeństw jest noszone przez nie swoiste piętno masowych mordów dokonywanych w imię zbrodniczych ideologii. Można więc chyba zasadnie lokalizować cezurę nowej ery w przededniu wybuchu I wojny światowej, a na pewno ery tej nie kończy jej punkt kulminacyjny, jakim była II wojna światowa wraz ze wszelkimi okrucieństwami popełnianymi przez różne strony

3 Warto przy tym zwrócić uwagę, jak sugestywna siła interpretacji Arendt sprawiła, że przyjęta przez nią optyka po pewnym czasie upowszechniła się do tego stopnia, iż prawie całkowicie zatarty został jej wybitnie dyskursywny charakter, a formuła „banalności zła” stała się nieomal intelektualną kliszą. O procesach asymilacji dyskursywnych tez Arendt pisał George Kateb [1984]. 
konfliktu: Niemcy, Związek Radziecki, a także Stany Zjednoczone, odpowiedzialne za zrzucenie bomby atomowej na japońskie miasta. Dlatego też xx-wieczne totalitaryzmy pisarz określa metaforycznym mianem prawdziwej zarazy, która nie tylko skutecznie skaziła jej siewców, ale także zatruwała i nadal zatruwa ludzkość jako taką, oswajając ją z widokiem masowo mordowanych ludzi, przyzwyczajając do obserwacji nieludzkich okrucieństw. Nie są to zatem tylko kwestie natury historycznej, ale mają także znacznie wykraczające daleko poza ściśle określone ramy czasowe. 9 września 1994 roku notuje pisarz w swoim Dzienniku... :

Czarną chmurą po totalitarnej zarazie jest Bośnia. Tchórzowskie komedianctwo zachodniej Europy i Ameryki (a tak nam się śpieszy, aby tam „wejść” w charakterze świeżo „nobilitowanych”) pozwala Karadżiciowi, rzeźnikowi z wyglądu i mentalności, robić, co chce, gwiżdżąc sobie z narad, pertraktacji, propozycji, dyplomatycznych zabiegów „panów i władców świata”. Czy ten rzeźnik nie jest typowym pogrobowcem totalitarnej dżumy, a jego potężni zalotnicy jej zatrutymi ofiarami? [Herling-Grudziński 1998: 256-257]

Zaledwie kilka dni wcześniej, w niezwykle pesymistycznym tonie, choć zarazem jednoznacznym i konsekwentnym wobec przyjętych przez siebie założeń, konstatował:

Po wielkich dżumach były zawsze w historii dłuższe czy krótsze okresy zachwiania wszystkich wartości, zamętu, utraty równowagi. A teraz? Po dżumie totalitarnej? Niektórzy filozoficzni mentorzy, religijni kaznodzieje, polityczni szalbierze pocieszają nas, że rozwiał się już dawno w powietrzu czarny dym wypalonej zarazy totalitarnej. A ja nie wierzę. Żyjemy i żyć będziemy moralnie w epoce napiętnowanej nią na długo, choćby nam mydlono oczy liczbami i dowodami „postępu”. [Herling-Grudziński 1998: 256]

Natomiast sam koncept społeczeństwa masowego jest według Herlinga-Grudzińskiego ściśle powiązany z totalitarnymi 
pokusami stworzenia „człowieka umasowionego”, jak pisał Friedrich Reck-Malleczewen, niemiecki arystokrata zamordowany w Dachau, lub „skolektywizowanego człowieka sowieckiego”, o którym pisał Grigorij Zinowiew w Zapiskach nocnego stróża [Herling-Grudziński 2017: 401-403] ${ }^{4}$. Ideałem byłoby zatem „wyhodowanie” (sic!) człowieka działającego sprawnie i bezrefleksyjnie, niestanowiącego potencjalnego zagrożenia dla precyzyjnie nastrojonej „machiny masowej produkcji eksterminacyjnej”. Człowieka, który w pełni zrzekłby się własnej odpowiedzialności i przeniósł ciężar moralnej winy za wszystkie swoje działania na jednostkę otoczoną nieograniczonym kultem i sprawującą absolutny rząd dusz. Bez różnicy, czy to będzie Eichmann $\mathrm{z}$ analiz Arendt, z jego podziwem dla Hitlera, który potrafił skutecznie narzucić wielkiemu społeczeństwu spójną wizję przyszłości i jednocześnie zmienić bieg historii całego świata, czy to będzie jeden z wyznawców Stalina i jego drogi ku lepszemu światu, o których wielokrotnie pisał Herling-Grudziński. W jednym i drugim przypadku prezentowane mechanizmy są niemal identyczne. Tak samo ułudne są również nadzieje wykonawców zbrodniczych nakazów na pozostanie po wszystkim ze względnie czystym sumieniem - co świetnie pokazała Arendt na przykładzie perfekcjonisty działającego na usługach niemieckiej machiny Zagłady.

\section{Krytyka Arendt}

Przy całej atencji pisarza do książki Arendt i jej koncepcji „banalności zła” w myśli Herlinga-Grudzińskiego można również zauważyć krytykę zogniskowaną wokół dwóch elementów. Po pierwsze, chodzi o ograniczenia poznawcze wynikające z zaproponowanego przez Arendt ujęcia głównej problematyki; po drugie, o pewną

4 Zagadnienia te w kontekście Innego Świata omawiał już Ryszard Kazimierz Przybylski [1991: 24-35]. To właśnie doświadczenie „innego świata” stało się bezpośrednim i jednocześnie kluczowym źródłem poglądów pisarza na temat istoty totalitarnej depersonalizacji jednostki [Wyka 1991]. O redukcji podmiotowości jako istotnym elemencie totalitarnego zniewolenia człowieka w koncepcji Arendt pisał Sigrid Meuschel [2004].

5 O kulturze jako formie oporu jednostki wobec unifikacji i zniewoleniu w pisarstwie Herlinga-Grudzińskiego pisał Leszek Szaruga [1997]. 
nieadekwatność jej teoretycznych wywodów do doświadczenia egzystencjalnego. Dodajmy jednak od razu, że krytyka ta miała wymiar dosyć ograniczony i nie dotyczyła całości pracy Arendt, ale wyłącznie jej pewnych fragmentów.

Pierwszym elementem krytyki pracy Arendt przez Herlinga-Grudzińskiego jest zatem koncentracja uwagi filozofki na złu i jego banalności, przy niemal całkowitym pominięciu istotnej obecność dobra, także wielokrotnie banalnego, choć jednocześnie (co ważne) posiadającego wymiar heroiczny. Tym samym obraz rzeczywistości staje się niepełny i aspektowy, co może zaburzać jego prawidłową analizę. Koncept „banalności dobra” pojawia się w Dzienniku pisanym noca [Herling-Grudziński 2018: 430-431] za sprawą książki Tzvetana Todorova [1991] Face a l'extreme (W obliczu sytuacji krańcowych), a później także przy okazji omówienia książki Enrico Deagalia [1991], zatytułowanej dokładnie w ten sposób: La banalità del Bene (Banalność dobra). To opowieść o Giorgiu Perlascu, włoskim zwolenniku generała Franco, który w przebraniu konsula wystawiał w czasie wojny listy żelazne węgierskim Żydom, uprzedzając tym samym działania zbrodniczej machiny sterowanej przez Eichmanna. Osobiście uratował w ten sposób ok. pięciu tysięcy Żydów [Herling-Grudziński 2018: 448-449]. W tym samym kontekście i na podobnych zasadach pojawiła się także u Herlinga-Grudzińskiego postać Dymitara Paszewa, prawicowego polityka bułgarskiego, który bardzo konsekwentnie sprzeciwiał się na forum parlamentarnym i rządowym dostosowaniu się przez Bułgarię do oczekiwań Hitlera dotyczących losów lokalnej społeczności żydowskiej. Zapis poświęcony opisującej tę historię książce mediolańskiego pisarza, Gabriela Nissimy, kończą niezwykle mocne, retorycznie ukształtowane, choć jednocześnie charakterystyczne dla Herlinga-Grudzińskiego [2000a: 164], słowa:

Panowie publicyści i żurnaliści polityczni niech posługują się ostrożnie obrazem dwudzielnego świata lewica - prawica. Drobną część skazanych na zagładę ofiar Holocaustu udało się uratować włoskiemu faszyście i bułgarskiemu politykowi prawicowemu. Kiedyś uczciwa lewica (w rodzaju PPs w Polsce) była synonimem Orwellowskiej „zwykłej przyzwoitości 
ludzkiej”. Komuniści, „lewicowi” ciemięzcy zawodowi, utopili to przekonanie w morzu krwi.

Oczywiście Herling-Grudziński doskonale zdawał sobie sprawę z ograniczeń własnej krytyki. W końcu Arendt napisała książkę o Eichmannie i jego procesie, a nie o czasach Zagłady jako takiej.Jednak przy tej okazji chciał podkreślić, że teza o „banalności zła" nie może być traktowana jako uniwersalne narzędzie do opisu zbrodniczych xx-wiecznych ideologii, w których możliwe było ocalenie choć części własnego człowieczeństwa (ze szczególną siłą teza ta wybrzmiewa w Innym Świecie). Podsumowywał pisarz:

Tymczasem lektura $W$ obliczu sytuacji krańcowych przekonała mnie, że Szałamow (a nie Sołżenicyn) po stronie sowieckiej, Primo Levi (a nie Borowski) po stronie hitlerowskiej wiedzieli najwięcej o „obozach totalitarnych”. [... ] W Rozbitkach, swojej ostatniej książce, pisat: „Ocean bólu, dawnego i obecnego, otaczał nas, jego poziom podnosił się z roku na rok, aż do pochłonięcia nas prawie”. Prawie... [Herling-Grudziński 2018: 431]

Drugi element częściowej krytyki Herlinga-Grudzińskiego związany był z tezą Arendt o ewentualnej przyczynie tak dużego zasięgu Holokaustu i skali jego ofiar, której myślicielka upatrywała częściowo w nadorganizacji społeczności żydowskiej. Według niej więcej trudności z dokonywaniem masowej zagłady mogło sprawić Niemcom społeczeństwo niezorganizowane, rozproszone i niemal anarchiczne w swej konstytucji, a więc z gruntu niezgodne $\mathrm{z}$ wysoce uporządkowanym mechanizmem totalitarnym. W swojej książce Arendt próbuje dowieść trafności tej kontrowersyjnej koncepcji, jednak Herling-Grudziński określa ją mianem wydumanej. Jednocześnie konstatuje, że nie wytrzymuje ona konfrontacji z doświadczeniem, które do pewnego stopnia było także jego udziałem.

Rewelacyjność książki zaćmiona jest przez jeden błąd, typowy dla badaczy totalitaryzmu o dość ograniczonych doświadcze- 
niach bezpośrednich. [...] Można ułożyć bogatą listę przyczyn, dla których teoria biernego oporu i nieposłuszeństwa bądź grzeszy intelektualną abstrakcją wykoncypowaną za biurkiem, bądź znajduje słabe zastosowanie w podobnych okolicznościach. [Herling-Grudziński 2018: 328-329]

Jedną z tych przyczyn, o której wielokrotnie pisarz wspominał, była szczególna sytuacja getta, „miasta oblężonego”, które znajdowało się nie tylko pod naciskiem wewnętrznym swoich oprawców, ale także innym, zewnętrznym i uprzednim naciskiem „stref względnej wolności”. Taki stan powodował zrozumiałą, reaktywną nadorganizację społeczności żydowskiej. Pisał Herling-Grudziński [2018: 328-329]:

W wielu krajach Europy - nie we wszystkich - żydowskie „miasta zamknięte” były oblężone podwójnie: fizycznie przez hitlerowców, psychicznie przez otaczające je narody podbite. Zbrodnia była dziełem hitleryzmu, toksyny sprzyjające zbrodni zatruwały powietrze europejskie na długo przed hitlerowskim „rozwiązaniem ostatecznym”.

Według pisarza dopiero pełne zrozumienie i przede wszystkim uwzględnienie tych okoliczności historycznych pozwala we właściwym kontekście umiejscowićjakiekolwiek sądy o karnym i bezwolnym poddawaniu się Żydów hitlerowskiej opresji.

\section{W obronie Arendt}

Przedstawione tu obiekcje wobec niektórych elementów analizy autorstwa Arendt w niczym nie umniejszały w oczach pisarza wartości całej książki, o czym - jak już wspominałem - Herling-Grudziński mówił otwarcie i wielokrotnie. Wręcz odwrotnie. Na łamach Dziennika... oraz w eseju Demon Naszych Czasów

6 W Demonie Naszych Czasów analizował także Herling-Grudziński [2016: 112] istotne w tym kontekście zagadnienie irracjonalnej nadziei na ocalenie, towarzyszącej ludziom do samego końca, nawet na progu komór gazowych. 
pisarz z dużym przekonaniem wdawał się w zaoczne spory z zaangażowanymi krytykami zarówno Eichmanna w Jerozolimie, jak $\mathrm{i}$ - przede wszystkim - sformułowanej w kontekście hitlerowskich zbrodni ludobójstwa koncepcji „banalności zła”. Zasadniczy kierunek owych krytyk, pomijając kwestie polityczne i historyczne, opierał się na zakwestionowaniu zasadności tytułowej formuły. Najprościej rzecz ujmując, polemika dotyczyła zatem tego, czy dostrzegając w złu jego banalność, nie odziera się go jednocześnie z przerażającego wymiaru, nie odbiera się jakiejś części wyjątkowości i grozy wydarzeniom tak dramatycznym, o jakich jest mowa. Innymi słowy, czy swoją analizą Zagłady, poprzez nadawanie jej wymiaru zdarzeń bolesnych, jednocześnie przejrzyście motywowanych i tym samym powtarzalnych (a więc nie dość wyjątkowych), Arendt nie podważa tego, że Zagładę należy uznać za skandal. W tym kontekście notował w Dzienniku... nieco zdziwiony i jednocześnie wyraźnie oburzony Herling-Grudziński [2018: 373]:

Nie wiedziałem wtedy, że niepoczytalna kampania przeciw Hannie Arendt w Ameryce i w Izraelu, posuwana do granic pomawiania jej o „antysemityzm”, główny nacisk kładła właśnie na ową „skandaliczną” jakoby „banalność Zła” [...] Gideon Hausner, prokurator w procesie jerozolimskim, oskarżył wręcz autorkę Eichmanna w Jerozolimie, że „wzięła w obronę zbrodniarza wojennego”. Bo czyż nie jest obroną tak monstrualnej zbrodni spychanie jej w rejony „banalności Zła” zamiast wzniesienia w rejony „demoniczności Zła”?

Obrona Arendt w wydaniu Herlinga-Grudzińskiego opierała się na trzech głównych tezach. Ich ignorowanie lub niedocenianie zarzucał pisarz adwersarzom analiz przedstawionych w Eichmannie $w$ Jerozolime.

Pierwszą tezę można nazwać antyideologiczną; sprowadza się ona do stwierdzenia, że wszystko, co napisała Arendt, ma mocne podstawy faktograficzne, bowiem badaczka opisuje rzeczywistość historyczną i w tym sensie jest niezależna od wtórnych i zewnętrznych wobec rzeczywistości koncepcji - bez względu na 
ich pochodzenie - oraz nawet najbardziej słusznych i przekonujących założeń i celów.

Druga teza nosi znamiona przestrogi sformułowanej przez człowieka, który na własnej skórze doświadczył, czym jest system zbrodniczej ideologii. Otóż dla autora Innego Świata nie do zaakceptowania było myślenie o hitlerowskim złu w kategoriach szczególnej wyjątkowości i niepowtarzalności, a więc traktowanie Zagłady jako niepojętego skandalu. Nie dlatego, że w ten sposób chciałby pomniejszyć ogrom zła i nieludzkie barbarzyństwo oprawców. Uważał podobne podejście za niebezpieczne i szkodliwe, ponieważ usypia czujność kolejnych pokoleń żyjących z nieusuwalnym piętnem obu wojen światowych, naznaczonych traumą XX-wiecznego masowego ludobójstwa jako „potomkowie” ocalonych. Według Herlinga-Grudzińskiego radykalnie zawęża ono pole analityczne i utrudnia odnajdywanie podobieństw we współczesnym świecie. To zaś w nieodległej przyszłości może doprowadzić do sytuacji, w której ponownie dojdą do głosu tymczasowo uśpione sily i nikt na czas nie będzie potrafil dostrzec płynącego z ich strony zagrożenia, gdyż wszyscy będą oddalać od siebie myśl o jakiejkolwiek historycznej analogii.

I wreszcie teza trzecia, ostatnia, sprowadza się do wniosków wypływających z bezpośredniej analizy idei „banalności zła”, która - wbrew jej krytykom - doskonale oddaje rzeczywistą naturę realnie działającego w świecie Zła (pisownia Herlinga-Grudzińskiego). Zdaniem pisarza mylą się twierdzący, że ukazanie prymitywnej natury Eichmanna i jemu podobnych odebrało diabelski wymiar całej zbrodni. Wręcz przeciwnie. Im bardziej pospolita twarz oprawcy, tym bardziej przerażają jego czyny; im bardziej podobny jest on do nas samych w swojej zwyczajności, tym mniej zrozumiałe wydają się jego postępki. Jak pisał Herling-Grudziński, pospolita i w gruncie rzeczy małostkowa motywacja wcale nie wyklucza demonicznego charakteru sił sprawczych. Nie czynią tego również najbardziej podstawowe błędy w myśleniu lub nawet jego całkowite zaniechanie ${ }^{7}$.

7 O roli myślenia i oceniania w analizie zła dokonanej przez Arendt pisali Bernstein [1996: 154-178] i Kristeva [2007: 151-159]. 
W ten sposób docieramy do najbardziej oryginalnego wymiaru odczytania tezy Arendt zaproponowanego przez autora Innego Świata. Zło obecne w świecie nie wyczerpuje się, według Herlinga-Grudzińskiego, jedynie w wymiarze zmysłowo doświadczalnym, ale posiada również nieusuwalny rdzeń metafizyczny. Zbrodnie hitlerowskie, a także komunistyczne, nie wynikają zatem wyłącznie z ludzkich ułomności i prymitywnych popędów, tylko noszą w sobie ślad zła istniejącego jako osobny, złowrogi byt. Powie Herling-Grudziński: ślad Zła, diabła [zob. Panas 2012: 40-56]. To napięcie między ludzkim i nie-ludzkim uważał pisarz właśnie za najważniejsze, także dla analiz samej Arendt i jej rewolucyjnej koncepcji „banalności zła”.

\section{Bibliografia}

Arendt Hannah (1963), Eichmann in Jerusalem. A Report on the Banality of Evil, The Viking Press, New York.

Arendt Hannah (1964), La banalità del male. Eichmann a Gerusalemme, Feltrinelli, Milano.

Arendt Hannah, Jaspers Karl (1992), Correspondence 1926-1969, przeł.

Robert Kimber i Rita Kimber, red. Lotte Kohler i Hans Saner,

Harcourt Brace \& Co, Orlando FL.

Arendt Hannah (1993), Korzenie totalitaryzmu, przeł. Mariola Szawiel

i Daniel Grinberg, NowA, Warszawa.

Bernstein Richard J. (1996), Hannah Arendt and the Jewish Question, Polity Press, Cambridge.

Bolecki Włodzimierz (2005), Ciemna miłość. Szkice do portretu Gustawa Herlinga-Grudzińskiego, Wydawnictwo Literackie, Kraków.

Deaglio Enrico (1991), La banalità del Bene [Banalność dobra], Feltrinelli, Luglio.

Heitzmann Daniela (2008), Coping with the Past: the Controversy regarding Hannah Arendt's „Eichmann in Jerusalem”, w: Totalitarianism and Liberty. Hannah Arendt in the 21 Century, red. Gerhard Besier, Katarzyna Stokłosa, Andrew Wisely, Księgarnia Akademicka, Kraków, s. 339-362.

Herling-Grudziński Gustaw (1963), Drugie Przyjście oraz inne opowiadania i szkice, Instytut Literacki, Paryż.

Herling-Grudziński Gustaw (1998), Dziennik pisany noca 1993-1996, Czytelnik, Warszawa. 
Herling-Grudziński Gustaw (2000a), Dziennik pisany nocą 1997-1999, Czytelnik, Warszawa.

Herling-Grudziński Gustaw (200ob), Tak, taki jestem, rozm. przepr. Anna Bikont i Joanna Szczęsna, „Gazeta Wyborcza”, 29 kwietnia 1 maja, s. 17.

Herling-Grudziński Gustaw (2016), Eseje, Wydawnictwo Literackie, Kraków, s. 105-114.

Herling-Grudziński Gustaw (2017), Dziennik pisany noca, vol. 1: 1969-1981, Wydawnictwo Literackie, Kraków.

Herling-Grudziński Gustaw (2018), Dziennik pisany nocą, vol. 2: 1982-1992, Wydawnictwo Literackie, Kraków.

Kateb George (1984), Hannah Arendt: Politics, Conscience, Evil, Martin Robertson, Oxford.

Kristeva Julia (2007), Geniusz kobiecy. Hannah Arendt. Biografia, przeł. Jacek Levin, KR, Warszawa.

Kudelski Zdzisław (1991), Czy pisarska porażka? (O „Dzienniku pisanym noca"), w: tegoż, Pielgrzym Świętokrzyski. Szkice o Herlingu-Grudzińskim, FIs, Lublin, s. 117-136.

Meuschel Sigrid (2004), The Institutional Frame: Totalitarianism, Extermination and the State, w: The Lesser Evil. Moral Approaches to Genocide Practices, red. Helmut Dubiel i Gabriel Motzkin, Routledge, London-New York, s. 109-124.

Naumann Klaus (1994), Sympathy for the Devil? Die Kontroverse um Hannah Arendts Prozeßbericht „Eichmann in Jerusalem”, „Mittelweg 36", nr 1, s. 65-79.

Panas Paweł (2012), Doświadczenia religijne w twórczości Gustawa Herlinga-Grudzińskiego, Wydawnictwo KuL, Lublin.

Przybylski Kazimierz (1991), Być i pisać. O prozie Gustawa Herlinga-Grudzińskiego, a5, Poznań.

Szaruga Leszek (1997), Szczerość i prawda, w: Herling-Grudziński i krytycy. Antologia tekstów, wybór i oprac. Zdzisław Kudelski, Wydawnictwo UMCS, Lublin, s. 15-16.

Todorov Tzvetan (1991), Face à l'extrême, Seuil, Paris.

Wyka Marta (1991), Nasz wiek wedtug Herlinga-Grudzińskiego, w: Etos i artyzm. Rzecz o Herlingu-Grudzińskim, red. Seweryna Wysłouch i Ryszard Kazimierz Przybylski, as, Poznań, s. 145-155. 
Paweł Panas

A Dispute over the Nature of Evil. Hannah Arendt in Gustaw Herling-Grudziński's Writings

The article attempts to trace Hannah Arendt's presence in Gustaw Herling-Grudziński's writing. The first time she appears in his texts is as the author of Eichmann in Jerusalem: A Report on the Banality of Evil - a book that the writer considered an exceptionally important voice in reflections about the nature of totalitarian systems and in the dispute over the nature of evil both in individual and metaphysical sense. Arendt's analyses of basic dehumanisation mechanisms were close to him; he is fascinated by the soundness of Arendt's key thesis on the 'banality of evil.' At the same time, Herling-Grudziński disputes with Arendt, indicating certain shortcomings in her thinking, mostly related to cognitive limitations resulting from her proposed take on the key problematics and partial disconsonance between theoretical disquisitions and existential experience. This criticism is limited and eventually Herling-Grudziński himself disputes with Arendt's main critics. These issues are discussed in the final section of the article.

Keywords: Hannah Arendt; 'the banality of evil'; evil; totalitarianism.

Paweł Panas - doktor habilitowany, literaturoznawca. Autor monografii: Doświadczenia religijne w twórczości Gustawa Herlinga-Grudzińskiego (2012), Opisanie świata. Szkice o poezji Marcina Świetlickiego (2014) oraz „Zagubiony wpośród obcych". Zygmunt Haupt - pisarz, wygnaniec, outsider (2019). Adres e-mail: pawel.panas@kul.pl. 